\title{
Determination of Organochlorine Residues in Cowpea (Vigna unguiculata L. WALP) From Selected Markets in Ibadan, Oyo State, Nigeria
}

\author{
O. O. Fadina, B. J. Daodu (Corresponding Author), O. O. Fayinminnu, C. S. Nwanguma
}

Department of Crop protection and Environmental Biology, University of Ibadan, Ibadan, Nigeria

Correspondance: B. J. Daodu, Department of Crop protection and Environmental Biology, University of Ibadan, Ibadan, Nigeria. E-mail: daodubj17@gmail.com, Tel: +2347031342890

Received: August 22, 2021 Accepted: November 9, 2021 Published: November 22, 2021

doi:10.5296/jas.v9i4.19228

URL: https://doi.org/10.5296/jas.v9i4.19228

\begin{abstract}
Cowpea (Vigna unguiculata(L.) Walp) is one of the major stale plant protein food crops in Nigeria, but constantly being attacked by insects especially during storage. This has been a major production constraint which usually necessitated the use of synthetic pesticides and chemicals, but comes with the problems of high pesticides residues. In cowpea, only few information or research has been made as regarding the level of pesticides residues, therefore the objective of this study was to identify the awareness level and organochlorine insecticides residue presence trendy to cowpea grains. This study was carried out using a multiple choice questionnaire, in which three markets in Ibadan were selected as the case study due to their population and patronisation. The multiple choice questionnaire was used in getting information as regarding the pesticide used, method of application, duration of storage after pesticide application and level of awareness on the possible side effects of pesticides. Thirty samples of cowpea were collected from the selected three markets for residue analysis which was determined in an analytical laboratory using standard procedures. Data collected were analysed using descriptive statistics. Results showed that Fumigation, spraying and baiting were the mostly used method of application of pesticides and Aluminium phosphide, Betoxin and Quickphos were the mostly used pesticides during application. Higher percentage $(56.67 \%)$ of the respondent store the food stuff for less than a month before exposing it to the market for sales, about $53.3 \%$ of the respondents shows their ignorance about the health hazard associated with pesticides. Organochlorine pesticide residues were detected in all the samples of cowpea grains examined with highest mean concentration of Endosulfan (0.7500 $\mathrm{mg} / \mathrm{kg} \mathrm{0.3508).}$
\end{abstract}


This study showed organochlorine pesticide residues presence trendy to cowpea grains and were generally above the recommend EU MRLs. Thus, lack of awareness on the harmful effects of these pesticides will lead to further health implications.

Keywords: cowpea, organochlorine, pesticides, residues, harmful effect

\section{Introduction}

Cowpea (Vigna unguiculata L. Walp) is one of the major staple plant protein food crops in sub-Sahara Africa (Adetiloyeet al., 2015). It has been observed to be an important food items within the ethnic groups in Nigeria. Nigeria retains the highest producer and consumer of cowpea globally with production of over $61 \%$ of total cowpea produced in Africa, of which 5.2 million tons of dried cowpea is produced in Africa and 5.4 million tons globally (FAO, 2016). Cowpea is an essential source of protein for vegetarian with low carbohydrate content and minerals such as copper, iron, sodium and potassium. Cowpea is harshly attacked at every stage of its growth and storage by a countless number of insects. It is mainly propagated by seed (Seka et al., 2014). Cowpea grains are essential in achieving food security in countries located in the sub-Sahara Africa. Production of this crop is threatened by diverse biotic constrains of which insect pest is the most devastating.

Insect pests inflict injury on these host crops in the course of their feeding on crop parts and these pests indirectly transmit diseases by acting as vectors of pathogens. These therefore constitute an important constraint in crop production. The different parts of cowpea are prone to an adopted pest species. Kamara et al. (2016) in his study reported that varying pod-feeding bugs, flower thrips and the legume pod borers were the major insect pests affecting cowpea in the dry savannas of North Eastern Nigeria. Seeds, flower, green pods and buds were attacked and damaged by Maruca larvae (Singh and Jackai, 2015). Flower bud abortion occurs as a result of thrips attack on flower bud initiation of cowpea (Akingbohungbe, 2012). Abnormal pod and seed formation arises from activities of adults and nymphs of pod bugs while removing sap from green pods (Singh and Jackai, 2015). Callosobruchus maculatus and the bruchid cause major losses in storage which could be as high as 90 percentage of cowpea kept in stores (Alebeek, 2016). Direct feeding of insect pests on stored cowpea inflicts damage resulting in its loss of value for planting, marketing or consumption. This resulted in indiscriminate use of chemicals by many cowpea farmers and traders to preserve these legumes for future sale; therefore, most harvested cowpea has high pesticide residues. "Nigeria was banned few years back by European Union (EU) from supply of cowpea with high level of Dichlorvos pesticide residue at 0.3 that exceeded the 0.1 acceptable limits." Nigeria exported cowpea is found to contain other chemicals like Omethoate, Chlorpyrifos, Trichlorphon, Cyhalothrin and Dimathoate at high, unacceptable levels. These indicate the use of the above pesticides either in the farm during cultivation or at storage (Akingbohungbe, 2012).

Previous losses recorded in the past suggested that substantial economic loss occurs with major pest of cowpea if left uncontrolled. Heavy losses in cowpea production is reported in Africa as a result of high incidence of insect pest and diseases. Farmers who applied Pesticides recorded a tenfold increase in yield as compared to uncontrolled plots. Due to the 
high incidence of insect pests on cowpea, farmers and producers of cowpea adopts the uses of pesticides. Some of these pesticides are abused, overused or pointlessly used by producers and traders with little knowledge on the mode of application or their hazard effects on food items (Olufade et al., 2014)

In Nigeria, insect pest remains a long persistent biotic stress of maximum cowpea both on field and storage. Recent observation in farmers' field planted with cowpea shows that farmers make conscious effort to protect their crops against insect pests through various control measures. Poor appropriate information dissemination and insufficient certified chemical product encourage production and sales of chemical agents that were banned globally for control of insect pests both on field and storage such as Lindane an organochloride insecticide (Fatoki and Awofolu, 2013; Sosan et al., 2015). Pesticide residues are found to be higher through diet than other medium for instance air and drinking water (Juraske et al., 2009). Pesticide excesses in food crops are not appropriately examined in Nigeria, only little information is available on the level of Pesticide excesses in cowpea, hence a need for this study.

\section{Cases of food poisoning in Nigeria}

There have been several reports on the danger and health hazard of pesticides usage in Nigeria, most of which were as a result of the indiscriminate and inappropriate use of these chemicals. These have led to food poisoning, some have led to death while others several health cases. An article titled 'Pesticide abuse: Growing concerns over poisoning of farm produce, livestock', Okon (2018) reported cases of food poisoning as a result of misuse of pesticides on food. In his first report was the case of a family that ate beans (cowpea) and pap (fermented corn meal) for breakfast in November 2018, after three hours of the meal, the husband and children started complaining of stomach upset with the pain increasing per minute, the husband began to limp and his tongue was stuck out of his mouth. The wife had to rush her husband to the hospital where he was immediately clasped with oxygen mask on his face; it took the doctor several hours before the man was revived. A sample of the meal was taken for analysis where Endosulfan and DDT insecticides residue was detected.

Another report from Okon (2018) on food poisoning in Adamawa revealed a whole family that died shortly after consuming 'moi-moi', a local delicacy from cowpea. Also in Bayelsa State, three family members, including a pregnant woman died in September after taking dinner. In August 2017, a family of five died after eating jollof rice in Anambra State. In September of that same year, six family members and a neighbour died after eating leaf porridge, known as 'fate' in Shinkafi, Zamfara State (Okon, 2018). All the cases were attributed to the wrong application and misused of pesticide, and also there are limited numbers of pesticide residues monitoring efforts in the country. The aims of this study was toward identifying the level of awareness of pesticide excesses among the retailers and food sellers selling cowpea in Ibadan selected markets and also to determine the occurrence and levels of organochlorine insecticides residues in cowpea in selected retailer markets in Ibadan. 


\section{Materials and Methods}

\section{The study area}

This study was carried out in three major markets in three Local Government Areas in Oyo State. These marketplaces were selected because they are the prevalent and utmost patronised marketplaces within the study region. The markets include: ShaSha (Sasa) market located along the Oyo road between Ojoo and the International Institute of Tropical Agriculture (IITA) in Akinyele Local Government of Oyo State. The market lies on latitude $7.4345^{\circ} \mathrm{N}$ and longitude $3.9154^{\circ} \mathrm{E}$ of the equator.

Bodija international market is a popular open market located in Bodija, a district in Ibadan North Local Government of Oyo State. As evident from its name, it was originally a fighting arena and it developed to be a reputable hub for the sales and distribution of food stuffs. The market is populated by different ethnic groups in Nigeria. The location of the market is close to the Oyo - Ogbomoso - Ilorin interstate road network. It lies on latitude $7.4359^{\circ} \mathrm{N}$ and longitude $3.9193^{\circ} \mathrm{E}$ of the equator. Oja Oba market also located in Ibadan North Local Government of Oyo State. It lies on latitude $7.342^{\circ} \mathrm{N}$ and longitude $3.819^{\circ} \mathrm{E}$.

\section{Sampling Techniques/ Administration of questionnaire.}

Simple random sampling technique was used to take samples from 30 traders and retailers of cowpea grains in the selected three markets i.e. (Bodija, ShaSha, and Oja Oba). Thirty samples of cowpea grains were randomly sampled; in each location (market) ten samples of cowpea grains were collected from each vendor. A survey on the awareness of possible pesticide residues in stored cowpea grains was carried out using a multiple choice questions questionnaire. The respondents were 30 retailers and traders of cowpea grains in the study area; ten respondents were sampled in each market. The questionnaire used was standardized and validated in the Department of Agricultural Extension and Rural Sociology, Faculty of Agriculture, University of Ibadan, Nigeria.

\section{Data collection}

Data were collected on basic information such as socio-demographic characteristics, the choice of pesticides, mode of application, type of pesticide use, length of storage after pesticide application and level of awareness on the possible side effects of pesticides by farmers and retailers often used on cowpea. 


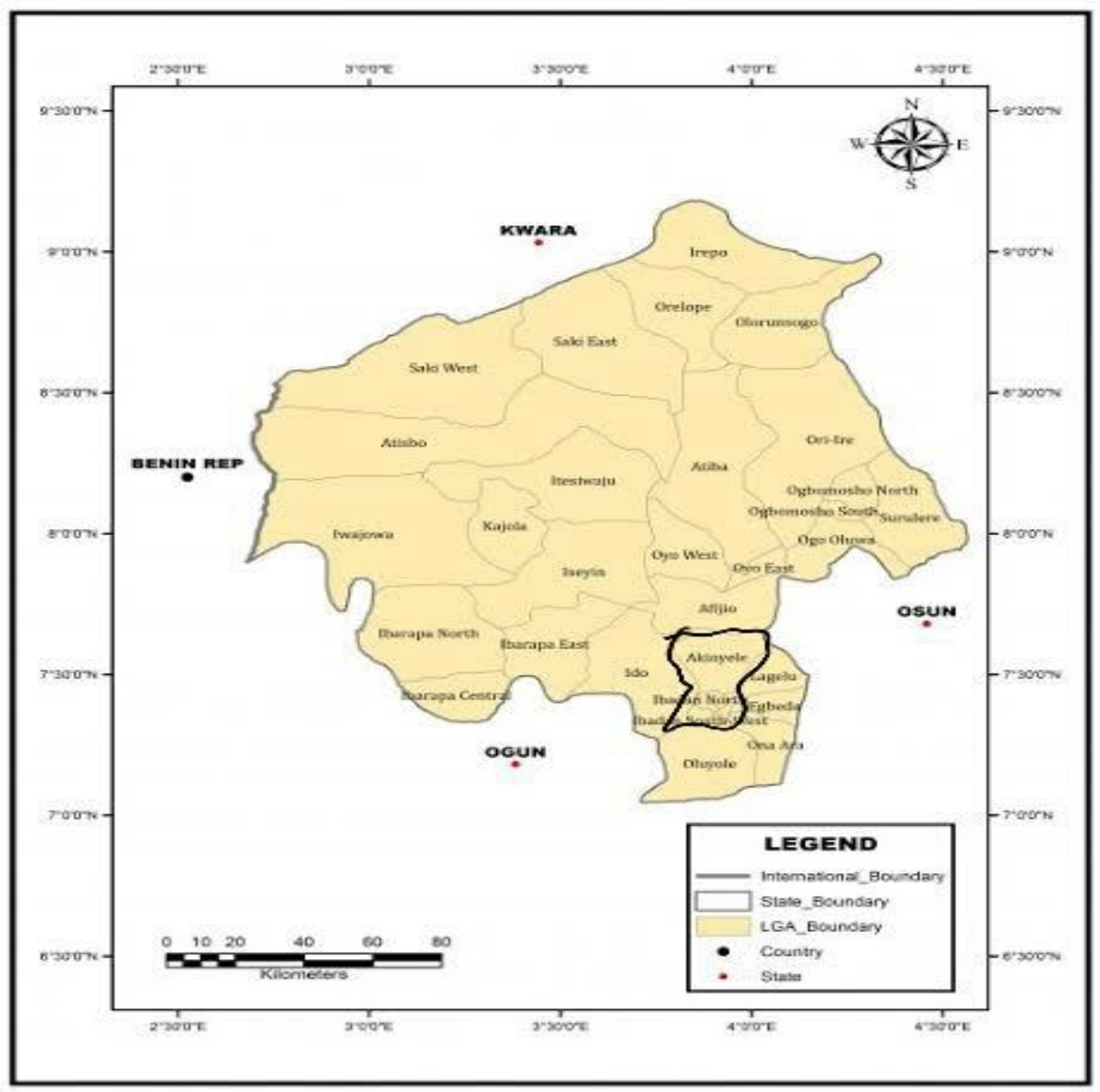

Figure 1. Map of Oyo State showing the study area marked in black (Akinyele, Ibadan North, Ibadan North East).

(Source: Google search engine 2019)

\section{Extraction}

The extraction and analysis of the pesticide residues were carried out at the Basel Convention Coordination Centre (BCCC), University of Ibadan, Ibadan, Oyo State, Nigeria. A $5 \mathrm{~g}$ of homogenised ground cowpea grains sample was weighed into a beaker and $25 \mathrm{~mL}$ of a mixture of acetone and hexane (1:1) was added. The beaker was sonicated for 10 minutes in an ultrasonic bath and the extract was transferred to another beaker. The extraction was repeated with $10 \mathrm{~mL}$ of the solvent mixture. The extracts were combined, concentrated to 


\section{Macrothink}

about $2.0 \mathrm{~mL}$ (BCCC, 2019).

\section{Clean-up Analysis}

Clean-up of the extracts was done with a column chromatography using silica gel, and then eluted with $5 \mathrm{~mL}$ of hexane. The purified extracts were then re-constituted in $2 \mathrm{~mL}$ hexane.

\section{Analysis using Gas Chromatography}

The discovery and resolve of the pesticide excesses were executed by dissolving the sample eluate in $1 \mathrm{~mL} \mathrm{n}$-hexane afore introducing $1 \mu \mathrm{L}$ of the $1.0 \mathrm{~mL}$ purified extract into the injection port of Agilent Technologies 7890 A equipped with 5975 MSD. The column consisted of a HP-5 Capillary column $(30 \mathrm{~m}, 0.32 \mathrm{~mm}, 0.25 \mu \mathrm{m})$. The column temperature was programmed at $75^{\circ} \mathrm{C}$ held for $0.5 \mathrm{~min}$, and then sustained at a rate of $10^{\circ} \mathrm{C} / \mathrm{min}$ to $300^{\circ} \mathrm{C}$ for $2 \mathrm{~min}$ so as to intensify decent resolution at different boiling points.

The temperature of the injector as well as the detector were $280^{\circ} \mathrm{C}$. The injection was carried out on a splitless injector at $280^{\circ} \mathrm{C}$ and the purge activation time was $30 \mathrm{sec}$. The carrier gas was Helium at $1.8 \mathrm{~mL} / \mathrm{min}$. Identification of pesticide excesses were actualised by means of reference standards and relative retention time procedures. The concentration of the excesses was determined by paralleling the topmost ranges of the samples with the equivalent topmost ranges of the reference standards of known concentrations.

\section{Analyte Residues Analyzed}

All the samples were examined for their organochlorine insecticides residues using the set up gas chromatographic equipped with the MSD. The average concentration of each pesticide was equated to the European Union (EU) Maximum residue limits (MRLs) database regulation. All data collected were analysed using (mean, standard deviation and standard error) IBM SPSS 20.

\section{Results}

The results from the administered questionnaires, eight $(26.67 \%)$ of the respondents adopted fumigation processes, twelve $(40.00 \%)$ of the respondents used spraying methods during insecticide application, six (20.00\%) used baiting method during pesticides application while four $(13.33 \%)$ did not use pesticides for storage but used the traditional methods such as sun drying, addition of pepper, storages in drums, as shown in Figure 2. 


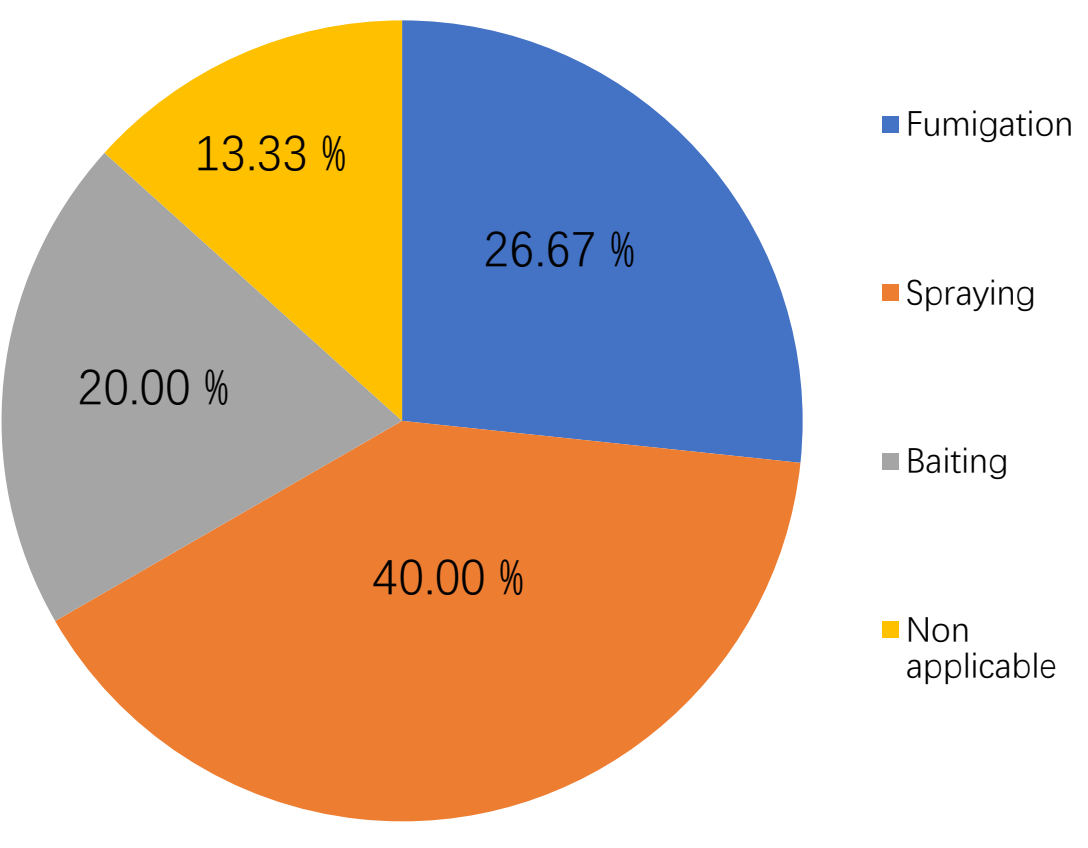

Figure 2. Methods adopted in pesticides application by the retailes and traders of cowpea grains

Results in Figure 3 indicate several pesticides used by cowpea grains traders in controlling pests from the selected markets. Three $(10.00 \%)$ of the respondents used only insecticides in controlling storage pests, four $(13.33 \%)$ of the respondents used only rodenticides in controlling storage pests, while nineteen $(63.33 \%)$ of the respondents used both insecticides and rodenticides in controlling storage pests. Only four $(13.33 \%)$ of the respondents did not depend on pesticides in controlling storage pests. 


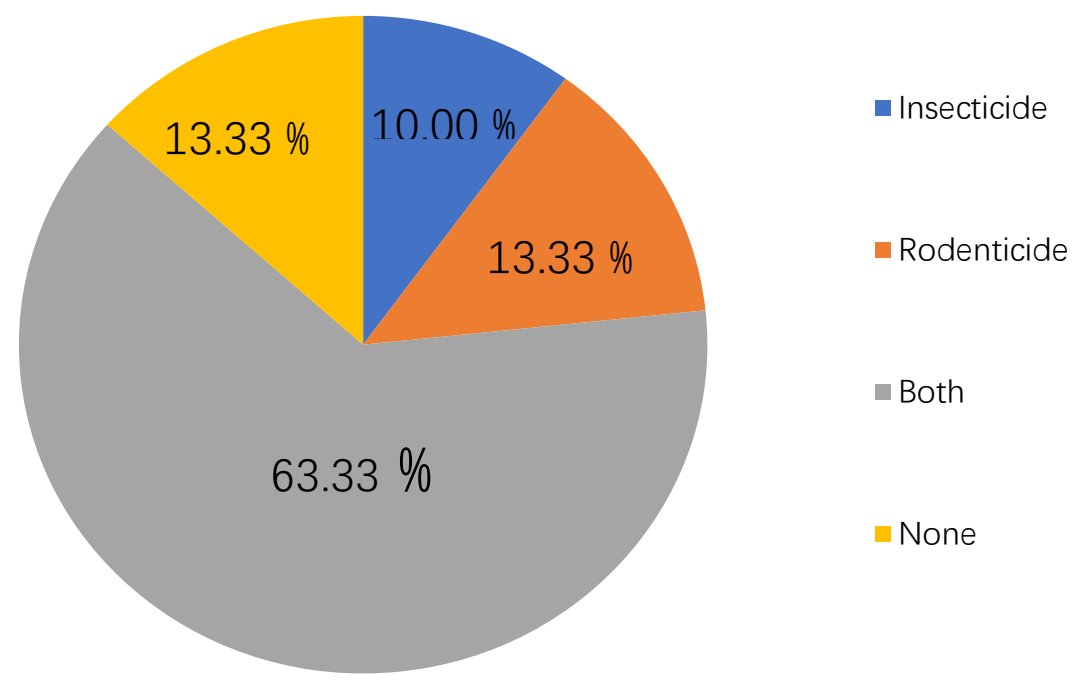

Figure 3. Percentage of pesticide usage among the cowpea retailers and traders

In Figure 4, seventeen (56.67\%) of the respondents stored the food stuff for about 30 days before selling, seven $(23.33 \%)$ allowed storage for about 2 months, four (13.33\%) allowed storage for 3 months before selling, while only two $(6.67 \%)$ of the respondents stored the food stuffs for 4 months before selling.

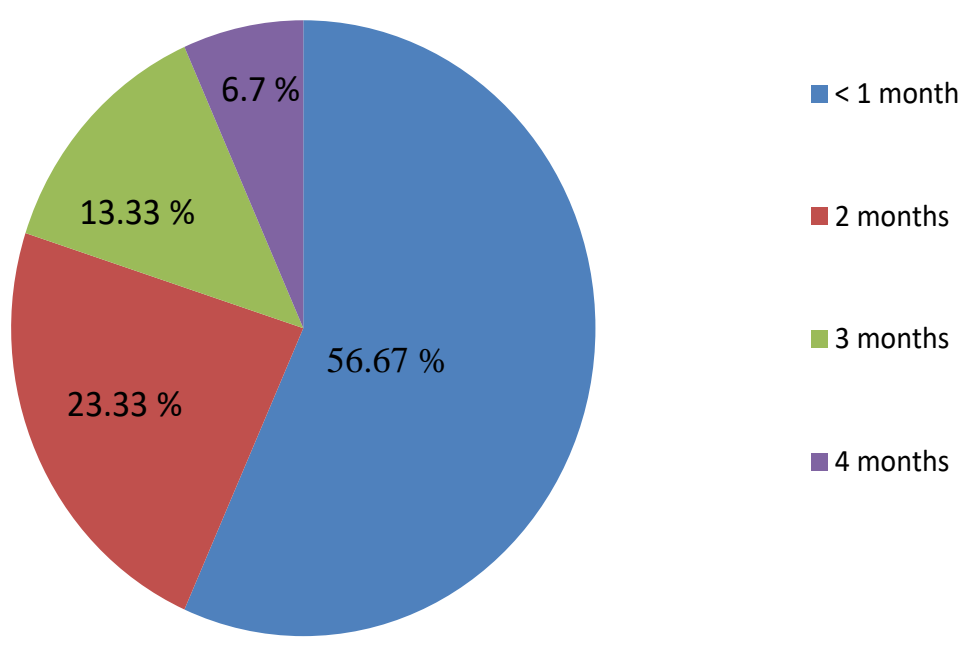

Figure 4. Duration of storage of cowpea garins after pesticides application

Results in Figure 5 shows the level of awareness of pesticides residues and toxicity among the cowpea grains traders from the selected markets. Sixteen $(53.33 \%)$ of the respondents were aware and well informed about the toxicities these pesticides possess, while 14 


\section{Macrothink}

Journal of Agricultural Studies

ISSN 2166-0379

2021, Vol. 9, No. 4

(46.67\%) of the respondents showed lack of knowledge about the toxicities of these pesticides.

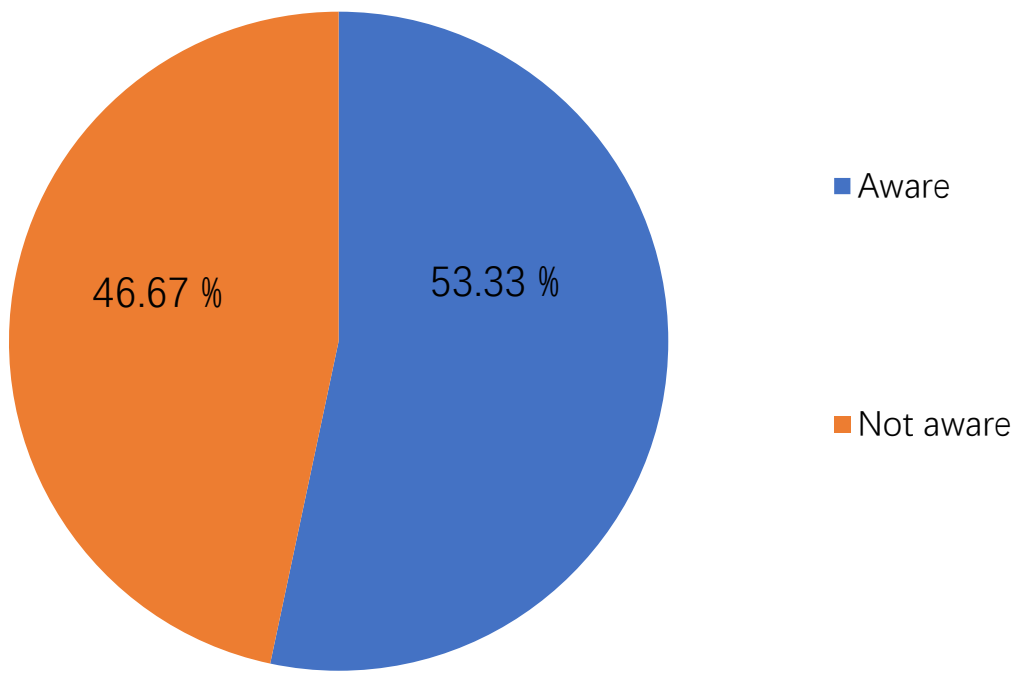

Figure 5. Level of awareness of pesticide residues among the cowpea retailers and traders from the selected markets

The mean concentration of all the cowpea grain samples that were collected from the three selected markets are indicated in Table 1 . The results of the analysis show 10 organochlorine insecticides residues were detected in all the samples. The detected residues with their mean concentration include; a-HCH $(0.0038 \mathrm{mg} / \mathrm{kg}), \mathrm{b}-\mathrm{HCH}(0.0029 \mathrm{mg} / \mathrm{kg}), \mathrm{d}-\mathrm{HCH}(0.0007$ $\mathrm{mg} / \mathrm{kg})$, Heptachlor epoxide $(0.0462 \mathrm{mg} / \mathrm{kg})$, Endosulfan $1(0.7500 \mathrm{mg} / \mathrm{kg}), \mathrm{p}, \mathrm{p}^{\prime}-$ DDE $(0.0049 \mathrm{mg} / \mathrm{kg})$, Endrin $(0.0165 \mathrm{mg} / \mathrm{kg}), \mathrm{p}, \mathrm{p}^{\prime}-$ DDT $(0.0042 \mathrm{mg} / \mathrm{kg})$, Endrin aldehyde $(0.0347$ $\mathrm{mg} / \mathrm{kg}$ ) and Methoxychlor $(0.0005 \mathrm{mg} / \mathrm{kg})$. The residues that were not detected include; Dieldrin, Endosulfan 11, p,p'- DDT, Heptachlor and Aldrin.

Table 1. Mean concentration $(\mathrm{mg} / \mathrm{kg}$ ) of Organochlorine excesses detected trendy to Cowpea grains from the three selected markets

\begin{tabular}{ccc}
\hline Pesticides & Mean \pm SE & Range \\
\hline a-HCH & $0.0038 \pm 0.0030$ & ND -0.0110 \\
b-HCH & $0.0029 \pm 0.0020$ & ND -0.0086 \\
d-HCH & $0.0007 \pm 0.0003$ & $0.0003-0.0013$ \\
Heptachlor & $\mathrm{ND}$ & $\mathrm{ND}$ \\
Aldrin & $\mathrm{ND}$ & $\mathrm{ND}$ \\
Heptachlor epoxide & $0.0462 \pm 0.0217$ & $0.0029-0.0701$ \\
Endosulfan I & $0.7500 \pm 0.3508$ & $\mathrm{ND}-2.2500$
\end{tabular}


p,p'- DDE

Dieldrin

Endrin

Endosulfan II

p,p'- DDT

Endrin aldehyde

p,p'- DDD

Methoxychlor

$\mathrm{SE}=$ Standard error $\quad \mathrm{ND}=$ Not Detected
ND

$$
0.0165 \pm 0.0086
$$

ND

$$
0.0042 \pm 0.0024
$$

$0.0347 \pm 0.0300$

ND
$0.0011-0.0071$

ND

ND -0.0204

ND

$0.0017-0.0065$

ND -0.1040

ND

In Table 2, the concentration of the insecticides from the cowpea grains across the three selected markets were compared with the EU's MRLs. Only four insecticides have their residues above the European Union Maximum Residues Limits, with Endosulfan I having the highest concentration of $0.750 \mathrm{mg} / \mathrm{kg}$, followed by Heptachlor epoxide with $0.046 \mathrm{mg} / \mathrm{kg}$, Endrin aldehyde with $0.035 \mathrm{mg} / \mathrm{kg}$ and Endrin with $0.017 \mathrm{mg} / \mathrm{kg}$. The concentration of a$\mathrm{HCH}, \mathrm{b}-\mathrm{HCH}, \mathrm{d}-\mathrm{HCH}, \mathrm{p}, \mathrm{p}^{\prime}-\mathrm{DDT}, \mathrm{p}, \mathrm{p}^{\prime}-\mathrm{DDE}$ and methoxychlor with 0.004, 0.003, 0.001, $0.005,0.004$ and $0.001, \mathrm{mg} / \mathrm{kg}$ respectively were below the EU's Maximum Residue Limits (MRLs).

Table 2. Pesticide Residues Detected in Cowpea Grains from the three marketplaces associated with EU's Maximum Residue Limits

\begin{tabular}{lcc}
\hline Pesticides & Mean & EU's MRL \\
\hline a-HCH & 0.004 & 0.01 \\
b-HCH & 0.003 & 0.01 \\
d-HCH & 0.001 & 0.01 \\
Heptachlor epoxide & 0.046 & 0.01 \\
Endosulfan I & 0.750 & 0.05 \\
p,p'- DDE & 0.005 & 0.05 \\
Endrin & 0.017 & 0.01 \\
p,p'- DDD & 0.004 & 0.05 \\
Endrin aldehyde & 0.035 & 0.01 \\
Methoxychlor & 0.001 & 0.01 \\
\hline
\end{tabular}

Number of sample $=30$

EU's MRL= EU's Maximum Residue Limit

Results presented in Table 3 shows the concentrations of the insecticides in cowpea grains 
samples from each selected market. In Oja Oba, only Endrin had it concentration above the EU's MRLs level with $0.0204 \mathrm{mg} / \mathrm{kg}$. Endrin, a- $\mathrm{HCH}$, and Heptachlor epoxide had their mean concentration above the EU's MRLs level with $0.0290,0.0110$, and $0.0701 \mathrm{mg} / \mathrm{kg}$ respectively in ShaSha market. However, Endosulfan I, Heptachlor epoxide and Endrin aldehyde had their concentration above the EU's MRLs level with 2.2500, 0.0656, and $0.1040 \mathrm{mg} / \mathrm{kg}$ respectively in Bodija market.

Table 3. Mean concentration of Pesticide Excesses ( $\mathrm{mg} / \mathrm{kg}$ ) Identified in Cowpea Grains from the three marketplaces associated with EU's Maximum Residue Limits

\begin{tabular}{llcc}
\hline Markets & Pesticides & Mean $(\mathrm{mg} / \mathrm{kg}) \pm \mathrm{SE}$ & EU's MRL \\
\hline \multirow{2}{*}{ Oja Oba } & Endrin & $0.0204 \pm 0.0014$ & 0.01 \\
Sha-Sha & a-HCH & $0.0110 \pm 0.0012$ & 0.01 \\
& Heptachlor epoxide & $0.0701 \pm 0.0071$ & 0.01 \\
& Endrin & $0.0290 \pm 0.0059$ & 0.01 \\
Bodija & Heptachlor epoxide & $0.0656 \pm 0.0068$ & 0.01 \\
& Endosulfan I & $2.2500 \pm 0.4012$ & 0.05 \\
& Endrin aldehyde & $0.1040 \pm 0.0203$ & 0.01 \\
\hline
\end{tabular}

Number of sample $=30 \quad \mathrm{SE}=$ Standard error $\quad$ EU's MRL $=$ EU's Maximum Residue Limits

\section{Discussion}

The main problem usually encountered by farmers, retailers and traders is the infestation of pests during the production and storage of cowpea grains (FAO, 2010). Nigeria being one of the highest consumers of cowpea and also it has been reported that cowpea serves as one of the main sources of cheap plant protein (Adedire and Gbaye, 2002). This study illustrated the problems encountered during the storage of cowpea grains in Ibadan markets which necessitate insecticides application to control with its residues being left on the foodstuff. The major pesticides used by the respondents in this study area were insecticides (Sniper, DD force, Cyperforce) and rodenticides (Phostoxin, Bextoxin, Toxibor, Quickphos). $13.33 \%$ of the respondents claimed to use only rodenticides, $10.00 \%$ claimed to use insecticides only, while $63.33 \%$ used the combination of both insecticides and rodenticides. Phostoxin which is usually used as fumigant insecticides is the most predominantly used pesticides in the study area. This was in agreement with the reports from earlier researchers (Deji, 2012; Adesina et al., 2015), that Phostoxin was found to be used mostly in preserving foods. Combination of two pesticides will have fast and quick effects on the pest of the foodstuffs but with adverse effects on the health of man with a higher tendency of pesticides residues Adesina et al. (2015).

It is worthy of note that $13.33 \%$ of the respondents did not use chemicals pesticides in controlling storage pests of cowpea grains. They used the cultural and traditional methods of controlling pests such as dry pepper, sun-drying and storage in barns. These respondents use dried pepper in powdered form on cowpea grains with the belief that dried pepper does not 
contain any known chemical or pesticide residues. They believed that food preserved in this way do not have any health risk when compared to pesticides. Although this method seems good and safe, but it can only be effective on a small scale. Majority of the respondents in the study area $(56.67 \%)$ stored foodstuff for less than a month before disposing it to the general public for consumption, this might result in food poisoning or contamination, and in agreement with the study by Adesina et al. (2015). Adesina et al. (2015) reported that storing of food crops for less than a month, might be because many do not understand the concept of withholding period which is the maximum length of time that must elapse. It is also a time a person must wait after application of pesticide on food crop before it is safe for consumption. Cases of about 20 fast food outlets closed in Nigeria due to the fatalities traced to pesticide residues in their food was reported by Chikwe (2010). Out of the thirty respondents interviewed, $53.33 \%$ of the respondents were aware of the possible pesticide residues and toxicities in cowpea grains, this they indicated by some claiming they used protection that is protecting themselves during the application of these pesticides. People with educational level up to the secondary school showed a good level of awareness of these pesticides toxicities. The respondents showed their willingness to stop using pesticides for storage if another alternative is provided for them to store their cowpea grains. Although, $46.67 \%$ of the respondents showed their lack of information and knowledge about the possible pesticide residues in the cowpea grains. It can be said that ignorance and lack of awareness also contributed to pesticides misused among the retailers and traders of cowpea grains in the study area.

Pesticide residues analyses showed that all samples contained one or more organochlorine insecticides. Their mean concentration in the cowpea grains samples from the selected three markets i.e. Oja - Oba, Sha Sha and Bodija markets indicated that some of their organochlorine insecticides residues were higher than the Maximum Residue Limit (MRL). The most occuring organochlorine residues in cowpea from these three markets with high values above the MRL were Heptachlor epoxide, Endosulfan, Endrin and Endrin aldehyde. The utmost principal residue in cowpea grains from these three marketplaces was Endrin, however the least concentration was Methoxychlor. Out of these insecticides detected in the samples from these markets, $\alpha-\mathrm{HCH}, b-\mathrm{HCH}, \mathrm{d}-\mathrm{HCH}$, Endosulfan I and p,p'-DDE, p,p'-DDD belong to WHO/EPA category II pesticides, which are moderately hazardous (WHO, 2010), while Endrin, Heptachlor- epoxide and Endrin aldehyde are categorised as obsolete pesticides by WHO/EPA. Most of these pesticides have been banned for use in food stuff and products by the European Union (Oladele et al., 2016).

The presence of these organochlorine insecticides indicated that the traders and retailers are fond of using banned pesticides for storage of their food produce. The organochlorine residues in cowpea grains maybe as a result of the high susceptibility of cowpea to insect proliferation which might necessitate pesticides to maintain good quality during storage and avoid economic losses. Although, the presence of some of these pesticides maybe as a result of long time application during planting and production as organochlorine pesticides are highly persistent in the environment. Other levels of organochlorine insecticides not detected in this study might be as a result of the gradual degradation of the pesticides in the 
environment. It is worth noting that these banned pesticides are still in circulation in Nigeria markets, where the marketers fail to abide with the restriction placed on these pesticides (Mokuwunye et al., 2014). Since Endrin and Heptachlor epoxide are the most predominant organochlorine residues from the three markets, Endrin has a similar structure with Aldrin and Dieldrin. The highly predominance of Endrin shows that Aldrin and Dieldrin have been metabolised to form Endrin.

Endrin is a stereoisomer of Dieldrin which can easily be metabolised in the environment. This however suggests that Endrin could be found in an environment where Dieldrin was previously applied. The ATSDR (1996) reported that Endrin does not dissolve very well in water and rarely found in air during agricultural application. The persistence of Endrin in the environment depends on the condition of application. Endrin can stay in soil for over 10 years. It is easily broken down when exposed to high temperatures at about $230{ }^{\circ} \mathrm{C}$ or light to form primarily Endrin ketone and Endrin aldehyde. Mode of exposure of Endrin and Endrin aldehyde into the body is through consumption, dermal and inhalation. When Endrin enters into the body, it bio accumlate in the fatty tissue of an organism and results into various harmful effects including severe central nervous system (brain and spinal cord) injury, convulsions, headache, dizziness, nervousness, confusion, nausea, vomiting, and might results to death (ATSDAR, 1996).

The mean concentration of the cowpea grains samples from Oja Oba market also showed that Endrin has the highest concentration over the EU MRL standard. This was in contrast with the report of Ogah et al. (2012), in which Endrin has the lowest concentration over the EU MRL in cowpea grains. The mean concentration of the cowpea grains samples from Sha Sha marketplace had three residues that were above the EU MRL which were a-HCH, Heptachlor epoxide and Endrin. Heptachlor epoxide is formed when Heptachlor undergoes oxidation process that is breakdown of Heptachlor in the presence of oxygen. Epoxides are always more toxic than its original form. The presence of these residues might be due to the past usage of them on cowpea during planting or the pesticides used during storage. Heptachlor is an effective pesticide against insect pests such as ant, termites, beetles and weevils etc. The mean concentration of the cowpea grains samples from Bodija international market also had three residues above the EU MRL. Endosulfan I had the highest, followed by Endrin aldehyde and Heptachlor epoxide. The mean concentration of this market was in agreement with the study by Olufade et al. (2014), where Endosulfan and Heptachlor were the residues with highest concentration above the EU MRL in cowpea grains.

\section{Conclusion}

Despite the restriction and bans on the use of most organochlorine insecticides in food produce by WHO (World Health Organization), Stockholm Convention of 2001 and European Union, it is still prevalent in use especially in the developing countries like Nigeria. This study confirmed that only few percentages of the traders and retailers of cowpea grains in the study area were aware of the dangers and health implication associated with using pesticides for storage. It can be said that ignorance, lack of awareness and proper education also contribute to pesticides misused among the retailers and traders of cowpea grains in the 
study area. It is therefore recommended that education, training and information on pesticide safety and management should be strengthened to increase awareness in the general public. Also, stern administration of protocols and consistent monitoring of pesticides excesses in food produces in Nigeria must be promoted for in minimising health hazards through food quality and safety.

\section{References}

Adedire, C. O., \& Gbaye, O. A. (2002). Seasonal prevalence and life history of the yam beetle, Dinocerus porcellus (Lesne) (Coleoptera: Bostrichidae) Nigerian Journal of Experimental and Applied Biology, 3, 323-329.

Adesina, G. O., Babarinde, S. A., \& Olaniran, A. O. (2015). Assessment of selected food products for pesticide residue in major markets of Oyo State, Nigeria. International Letters of Chemistry, Physics and Astronomy Online, 54, 47-55. https://doi.org/10.18052/www.scipress.com/ILCPA.54.47

Adetiloye, P. O., Okeleye, K. A., \& Olatunde, G. O. (2015). Principles and practices of crop production. BIIM Nig. Ltd., pp. 201-214.

Agency for Toxic Substances and Disease Registry, ATSDR (1996). Toxicological profile for endrin. Atlanta, GA: U.S. Department of Health and Human Services, Public Health Service.

Akingbohungbe, A. E. (2012). Seasonal Variation in Cowpea Crop Performance at Ile-Ife, Nigeria and the Relationship to Insect Damage. International Journal of Tropical Insect Science, 3(4), 287-296. https://doi.org/10.1017/S1742758400002058

Alebeek, F. A. N. (2016). Natural suppression of bruchid pests in stored cowpea (Vigna unguiculata (L.) Walp) in West Africa. International Journal of Pest Management, 42, 55-60. https://doi.org/10.1080/09670879609371970

Awofolu, R. O., \& Fatoki, O. S. (2013). Persistent organochlorine pesticide residues in freshwater systems and sediments from the Eastern Cape, South Africa.Water SA, 29(3), 323-330. https://doi.org/10.4314/wsa.v29i3.4934

Chikwe, A. (2010). National Agency for Food and Drug Administration and Control axes 20 fast food outlets. Task operators on good hygienic Practices, Tuesday, July 6, 2010. www.nigerianbestforum.com

Deji, S. A. (2012). Awareness of pesticide residues in locally available food and condiments among food sellers: a case study of Osun state, Nigeria. Journal of Public Health in Africa, 3, 26. https://doi.org/10.4081/jphia.2012.e26

FAO (2014). Food and Agricultural Organisation of the United Nations. www.fao.org/statistics/en/ FAO, Rome.

FAO (2016). Food and Agricultural Organisation of the United Nations. www.fao.org/statistics/en/ FAO, Rome.

Juraske, R., Anton, A., Castells, F., \& Huijbregts, M. A. (2009). Human intake fractions of 
pesticides via greenhouse tomato consumption: comparing model estimates with $\begin{array}{llll}\text { measurements for } \quad \text { Captan. } & \text { Chemosphere, 67(6), }\end{array}$ https://doi.org/10.1016/j.chemosphere.2006.11.047

Kamara, A. Y., Ellis-Jones, J., Amaza, P., Omoigui, L. O., Helsen, J., Dugje, I. Y., ... White, R. W. (2016). A participatory approach to Increasing Productivity of Maize through Striga hermonthica control in Northeast Nigeria. Experimental Agriculture, 44, 349-364. https://doi.org/10.1017/S0014479708006418

Mokuwunye, I. U., Babalola, F. D., Asogwa., U. E., Aderolu, I. A., \& Mokwunye, M. I. (2014). Compliance of agrochemical marketers with banned cocoa pesticides in Southwest Nigeria, Journal of Agricultural Science, 59(2), 161-174. https://doi.org/10.2298/JAS1402161M

Ogah, C. O., Tettey, J., Coker, H. B., \& Adepoju-Bello, A. A. (2012). Analysis of organochlorine pesticide residues in beans from markets in Lagos State, Nigeria. WestAfrican Journal of Pharmacy, 23(1), 60-68.

Okon (2018). Nigeria bans 30 pesticides after rash of poisoning. The Journal of Pesticide Action Network, UK 80, 23-25.

Oladele, A. O., Ajiboye, E. O., Adebayo, T. A., Babarinde, S. A., Adedosu, H. O., \& Adesina, G. O. (2016). Determination of organochlorine pesticide residues in dried cocoa. $\begin{array}{lllll}\text { International Letters of } & \text { Natural } & \text { Sciences, } & 54, & 8-16 .\end{array}$ https://doi.org/10.18052/www.scipress.com/ILNS.54.8

Olufade, Y. A., Sosan, M. B., \& Oyekunle, J. A. O. (2014). Levels of organochlorine insecticide residues in cowpea grains and dried yam chips from markets in Ile-Ife, southwestern Nigeria: a preliminary survey. Ife Journal of Science, 16, 2-5.

Singh, S. R., \& Jackai, L. E. N. (2015). Insect pests of cowpeas in Africa: their life cycle, economic importance and potential for control. Pages 217-231 in cowpea research production and utilization, edited by S.R. Singh and K.O. Rachie. John Wiley and Sons N.Y.

Sosan, M. B., Akingbohungbe, A. E., Ojo I. O., \& Durosinmi, M. (2015). Pesticide residues in the blood serum and domestic water source of cacao farmers in Southwestern Nigeria. Chemosphere, 72, 781-784. https://doi.org/10.1016/j.chemosphere.2008.03.015

\section{Copyright Disclaimer}

Copyright for this article is retained by the author(s), with first publication rights granted to the journal.

This is an open-access article distributed under the terms and conditions of the Creative Commons Attribution license (http://creativecommons.org/licenses/by/4.0/). 